\title{
Runet in Crisis Situations
}

\author{
Gregory Asmolov
}

\section{Introduction}

While the World Wide Web is a relatively recent invention, some scholars and writers had already envisioned networked structures that linked people together many years prior to the rise of the Internet. One early model of the Internet can be found in the novel Timur and His Squad (1940) by the Soviet writer Arkady Gaidar. Gaidar describes a vigilante group of children who in secret undertake to do a charitable activity and protect their fellow villagers from local hooligans. The secret headquarter of their organisation is in an old barn at the centre of which is a steering wheel linked through a network of strings to the houses of all members of this secret organisation. Whenever Timur, the leader of the squad, needs his team, he uses the wheel to call them. The number of times he turns the steering wheel indicates the different types of alert or calls for help. Strings can also be connected to or disconnected from the wheel in order to call on specific members of the network. The wheel is a tool that allows targeted mobilisation of the resources of a distributed network in a crisis situation. Using the wheel both define the crisis and address it. It also constitutes the nature of the informal network of Timur's squad. To what extent, we may ask, does Runet embody Gaidar's networked mobilisation wheel vis-à-vis their respective capacity to response to emergency situations?

Research on the Internet, and specifically Runet, has addressed a broad range of issues including the economy, digital literacy and the digital divide, regulation, media, security, politics, social movements and games. While all these topics appear diverse, most of them share a common denominator. They each deal with issues that

This work was funded as a part of Leverhulme Trust Early Career Fellowship.

G. Asmolov ( $\square)$

Russia Institute, King's College London, London, UK

e-mail: gregory.asmolov@kcl.ac.uk

S. Davydov (ed.), Internet in Russia, Societies and Political Orders in Transition, https://doi.org/10.1007/978-3-030-33016-3_12 
are related to the everyday life of users. However, there is one issue which is distinctively different from everyday life: crisis situations. The purpose of this chapter is to explore the role of Runet in crisis situations. To address this issue, we first need to define the term "crisis" and how to conceptualise the role of digital platforms in crisis situations.

\section{Role of Digital Platforms in Crisis Situations}

There is an ongoing discussion about the notion of crisis (Coombs, 2010). Seeger et al. propose that "a crisis may be defined as a specific, unexpected, non-routine event or series of events that creates high levels of uncertainty and a significant or perceived threat to high priority goals" (cited in Sellnow \& Seeger, 2013, p. 7). Rosenthal and Kouzmin (1993) distinguish between intentional man-made crises and natural external causes. Lerbinger (1997) distinguishes between "crises of the physical world" (e.g. natural disasters), crises of the "human climate" (e.g. criminal actions and political conflicts) and "crises attributable to management failure" (pp. 15-16). James and Wooten (2005) offer typology that relies on differentiation between sudden and smouldering crises. According to them, natural disasters, terror attacks, explosions and technological incidents can be considered as unexpected sudden crisis situations. Weick (1993) addresses a crisis as a cosmological episode, where "people suddenly and deeply feel that the universe is no longer a rational, orderly system" (p. 633).

The notion of crisis, however, cannot be distinguished from people's behavioural changes in response to a crisis. Sellnow and Seeger (2013) point out that "When people believe there is a crisis, they are likely to behave differently than they would in so-called normal times" (p. 5). According to Barton (1969), the transformation of society in the face of crisis can be conceptualised as a transition from an everydaylife social system to an "emergency social system", suggesting an alternative normative structure, behaviour and set of roles that are formed around the need to address the crisis and resolve it "either by starting new activities to meet people's needs or by inducing people to accept a lower standard of goal achievement" (p. 66). This may include polar forms of behaviour including a significant rise of altruism or the opposite, antisocial and violent behaviour (Barton, 1969; Sorokin, 1942). According to chaos theory, crisis opens up a space for new forms of self-organisation and is necessary for evolution to a higher order (Sellnow \& Seeger, 2013, p. 110). Solnit (2010) suggests that crisis presents a window of opportunity in which new types of society, driven by altruism, can be introduced. Emergency situations can be also approached as moments of technological innovation and sociopolitical development, driven as they are by the need to address the crisis (Cuny, 1983).

From an informational point of view, a crisis can be considered as the "production of uncertainty" (Sellnow \& Seeger, 2013, p. 258). Flows of communication around crises can both diminish uncertainty and increase a degree of confusion and mistrust. One of the central issues in crisis communication is the cause of the crisis and who needs to be held accountable for it (Coombs \& Holladay, 2004). At the same time, communication also has an instrumental dimension and can provide instruction on 
how to survive and how to address the crisis. However, communication is not only the process of information provision about a specific crisis; it also constitutes the core process in constructing the crisis: "Defining an issue as a crisis means that some action must be taken in response and that resources should be made available" (Sellnow \& Seeger, 2013, p. 10).

The link between the construction of the crisis and the mobilisation of resources to respond to the crisis highlights the broad role of digital technologies in crisis situations. The role of digital platforms and social networks in crisis situations is not limited to increasing transparency around these situations, the attribution of responsibility for them and holding someone accountable. Various forms of crowdsourcing practices have the potential to allow the resources of digital users to be mobilised to respond to a crisis (Asmolov, 2014; Meier, 2015). While the availability of big data (Castillo, 2016) and user-generated information contribute to the capacity to construct the crisis, crowdsourcing practices support various types of online and offline activity that can be considered part of an emergency response (Meier, 2011; Ziemke, 2012).

In this way, the role of digital technologies for defining what crisis is and for the facilitation of emergency response is interrelated. Digital technologies play a dual role while they mediate meaning (Silverstone, 2002) as a part of the crisis construction and mediate activity (Leontiev 1978; Vygotsky, 1978) as a part of the crisis response. In that sense, the role of digital platforms and the Internet in particular can be approached as a mediator between users and crisis situations. Various forms of digital mediation constitute the position of users in regard to a crisis either as passive spectators of the crisis or active participants in the emergency response. The mediational perspective on technologies (Kaptelinin, 2014) suggests that we're asking about mediation opportunities that could offer new forms of relationship between user and crisis. The role of digital platforms in the mediation of the usercrisis relationship can, however, differ depending on the cultural and sociopolitical context.

In some cases, digital platforms mediate collaboration between traditional institutions and Internet users. In other cases, the digitally mediated mobilisation of citizens' resources addresses traditional institutions' lack of appropriate emergency response. The latter makes any type of crisis, including natural disaster, a sensitive political issue. Pelling and Dill (2006, pp. 4-5) suggest that "the failure of the state to respond adequately to disaster can create a temporary power vacuum" and call for "opening to scrutiny dominant political and institutional systems". Hewitt (1998) highlights that in situations of natural disaster, one of the major goals of emergency management by the authorities is to control the population in affected areas rather than to respond to the disaster. In that context, traditional institutions also seek to use the media to construct the crisis either, that is, to avoid criticism and responsibility, and/or to legitimise action that is more radical than that which is considered acceptable in the context of everyday life.

In that light, digital affordances (Hutchby, 2001) and mediational opportunities for the mobilisation of the digital crowd's resources, as well as users' participation in crisis-related activities, can be interpreted and realised in substantially different ways in different sociopolitical and cultural contexts. In other words, similar tools can play 
a substantially different role in the construction of meaning around crisis, offer different modes of relationship between citizens and traditional state institutions as well as introduce different types of crisis-related activity systems (Engeström, 1987). Therefore, investigation of the role of digital platforms for crisis communication requires not only interdisciplinary but also intercultural comparative projects, which cross the borders of national states (Schwarz, Seeger, \& Auer, 2016).

As such, this study concentrates on a specific segment of global cyberspaceRunet. A focus on the Russian Internet, also known as Runet, provides us with a specific case for examining the role of a national segment of the World Wide Web in situations of crisis. The notion of Runet requires further clarification. As argued by Schmidt and Teubener (2006) the boundaries of Runet may rely on a variety of factors including "language, technology, territory, cultural norms, traditions or values and political power" (p. 14). In this chapter Runet is addressed as a sociocultural segment of cyberspace that is dominated by Russian language content and Russian language social interaction and open to Russian-speaking users from all over the world. However, the notion that Runet as a dedicated term for a specific segment of cyber space "has almost no analogue in Western languages" (Schmidt \& Teubener, 2006, p. 14) also requires specific attention. "Runet" as a concept can also be considered as an object of continuous social construction and, accordingly, a set of dominant and alternative Internet imaginaries of the information environment that are promoted by different actors who belong to the Russian scientific, technological, cultural, media and political elites (Asmolov \& Kolozaridi, 2017).

This chapter is focused on exploring the role of Runet in the mediation of meanings and the mediation of activities around crisis situations. It asks "What role does Runet play in the construction of crisis and in crisis response participation"? New forms of digital mediation of user-crisis relationships are explored as a manifestation of digital innovation that seek to address crisis-related challenges. The role of digital innovation is addressed in terms of how digital platforms that have been used by Runet users constitute their position in regard to crisis situations. In addition, digital innovation is also explored in the context of relationships between Internet users and traditional institutions that are responsible for crisis response. Finally, responding to the above questions may assist in the examination of how digital innovation in crisis situation can be associated with the development of Runet in everyday life.

\section{Russia and Crisis Situations: A Sociopolitical Context}

Russian history includes key episodes when natural disasters had political consequences. For instance, famine and fires in what is called the "Time of Troubles" ("Smutnoe vremya") number among the factors linked to political instability during the regency of Boris Godunov (1601-1603). Alexander Pushkin (1825) described Godunov's frustration about the people's lack of appreciation for his actions in response to the crisis: "They blamed me for the fire! Such is the mob". According to 
Barton (1969), "In nineteenth-century Russia the overcentralisation of power by the Tsar left local government so weak and unpopular that its efforts to control a disaster led to riots, and there was massive disobedience" (p. 293). That said, in the nineteenth century volunteer firefighters "consistently supported the traditional values of an authoritarian state" (Raab, 2011, p. 4). In the USSR, the authorities made a significant effort to conceal information about disasters, as in the case of the nuclear explosion in Chernobyl which was addressed by the state with a "politics of invisibility" (Kuchinskaya, 2014). Samoilenko (2016) argues that blame games, shifting responsibility and concealing crises are traditional practices for Russian institutional actors which can be approached as a legacy of Soviet totalitarian practice in which the state plays a dual role as both "crisis manager" and as "risk producer" (p. 406). Roffey (2014) argues that concealment of the "real magnitude of the problem" can often be seen in Russia:

There is a risk that a natural disaster and the crises it generates will undermine the influence and legitimacy of key actors and leaders. Controlling the flow of information to the public is therefore seen as essential. (Roffey, 2014, p. 79)

Bertrand (2012) also points out that during the wildfires of 2010 the government sought "to hush up the role played during the emergency phase by a large and spontaneous organisation of citizens" to allow the government "to construct an image of a capable state and leaders to prevent any loss of credibility at the national and international levels" (p. 39).

To explore the role of Runet in crisis situations this chapter suggests focusing on three types of emergency. The first type of crisis is major incidents and terror attacks. The second type of crisis are natural disasters; the chapter looks specifically into the role of Runet in response to wildfires in 2010. Finally, some additional aspects of the role of Runet in crisis situations are explored through a focus on domestic and international conflicts. That includes internal political unrest, specifically protests around the parliamentary and presidential elections of 2011-2012 and international conflicts, specifically the conflict between Russian and Ukraine. All three situations offer an opportunity to examine the role of Runet in its transition from everyday life to emergency-related social systems and the various modes of digitally mediated user-crisis relationship that are linked to this transition.

\section{The Role of Runet in the Constitution of the User's Position in Crisis Situations}

\subsection{Major Incidents, Terror Attacks and Alternative Sources of Data}

One of the major characteristics of crisis situations is a contradiction between a scarcity of information and the immediate demand of the public to know what is happening. This contradiction may become even more significant in political environments in which the major traditional media are controlled by government and 
where there is some degree of mistrust in the information that is distributed through official media. Even before Runet became known as Runet, it provided sources of independent information about crisis events. For instance, during the Putsch events of August 1991, UseNet newsgroups were used by members of the Relcom and Demos networks to share information about what had happened in Moscow (Soldatov \& Borogan, 2015).

Runet started to play a role as an alternative source of information at the time of several major terror attacks in the first half of the 2000s, when state-controlled TV channels were increasingly criticised for censoring essential information about crisis situations (Lipman, 2006). These included the hostage taking during the Nord-Ost musical in Moscow in 2002 and in a school in Beslan in 2004 (Peterson, 2005, p. 79). Independent online media were the central source of information at these times. That said, information was also circulating via Runet, mostly in the Livejournal blogosphere, a popular platform in the mid-2000s. One of the reasons for the blogs' increasing role was that a number of well-known journalists used Livejournal for personal blogging in addition to reporting to their media organisations. In some cases, first-hand information was also published by eyewitnesses and relatives of the hostages. The role of Runet at the time of the terror attacks was not limited to Russia. Israeli Russian-speaking users of Livejournal created a dedicated online community, "Pereklichka_il" (roll call), to check the safety of bloggers following terror attacks in Israeli cities. ${ }^{1}$ This community can be considered as an early prototype of Facebook's safety check application.

User-generated content came to play a particularly significant role when an incident took place in a highly populated environment, for instance, a fire in a tall building in the Setunsky neighbourhood of Moscow in November 2005, when eyewitnesses from the surrounding buildings shared photos online in real time. Information generated by the users of Runet, including bloggers and members of local forums, often offered first-hand information about emergency situations almost in real time in a number of incidents and terror attacks, particularly when the event took place in an urban area or in proximity to a substantial number of Internet users who were able to document and share information about the incident using their personal computers and mobile phones. This included the crash of a Boeing in Perm in 2008, a terror attack on the "Nevsky Express" train in November 2009 (Asmolov, 2009a) and a fire in the "Khromaya Lochad" club in Perm (Asmolov, 2009b). Groups dedicated to these incidents were created on social networks such as Vkontakte and these were used for sharing information about what had happened. User-generated online content about the incidents also started to be actively used by traditional media.

Another practice that emerged in the context of the coverage of major incidents and terror attacks was the memorisation of the personal pages of the victims. For instance, a number of the passengers and flight attendants who tragically died in the aforementioned 2008 Boeing crash had personal webpages on the popular social

\footnotetext{
${ }^{1}$ https://pereklichka-il.livejournal.com/
} 
network Vkontakte. Following the tragedy, dozens of users left comments with condolences on the personal profiles. These profiles were also used as a source of information by traditional media.

With the growing popularity of Twitter in Russia, substantial coverage of incidents started to circulate with hashtags. Hashtags enable the emergence of a common denominator for a feed of information around specific events. Moreover, while some hashtags referred directly to an event (e.g. \#Domoded24 in the case of a terror attack on Domodedovo airport or \#Metro29 in that of the terror attack on the Russian underground), other hashtags referred to specific aspects or forms of activity related to the event, for instance, those that helped people in the area of the incident to find alternative free transport. Twitter also contributed to the rapid proliferation of information through its simple reposting feature.

Social media gradually became a legitimate source of information for traditional media. It also challenged the state's framing of and narrative around the scale of the incident and the efficiency of the response. That said, multiple sources of information online also contributed to an information overload, a lack of clear and consistent pictures of the events, and they also increased the threat of the proliferation of unverified information and rumours. In response to this challenge, users of Runet introduced a new bottom-up practice that allowed verified information from social media and traditional media to be gathered in the same place. This is the practice of the development of ad hoc websites that appear in the first hours after an event to aggregate - in one and the same place-information from a variety of sources. One of the first websites of this type Vlfire.org was set up in response to a fire that had occurred in an office building in Vladivostok in 2006. The website was also used to hold the local authorities accountable following the incident.

In some cases, an ad hoc project would be named after the hashtags given to the event on Twitter. For instance, a few hours after the terror attack on the Moscow underground on March 29, 2010, the webpage metro29.ru was set up to aggregate information about the tragedy. A similar type of ad hoc website was developed during the 2011 terrorist attack on Domodedovo airport. The platform Domoded 24 . com "served as a source for essential information, such as names of casualties and wounded as well as lists of volunteer drivers" (Machleder \& Asmolov, 2011). The role of these ad hoc websites and social media platforms went beyond providing an alternative source of information and contradicting the official media frames. It constituted the position of users in regard to crisis not only as information sources but also a resource that can be mobilised to show mutual aid and assist those affected by the crisis. The full spectrum of Runet's functions in crisis situations can be explored through addressing emergencies which have a broader geographical scope and which continue over a longer period of time. This requires focusing on and examining responses to natural disasters. 


\subsection{Natural Disasters and Crowdsourcing}

In summer 2010 wildfires broke out in different locations in Western Russia. More than 60 people died, and the unofficial number of casualties was higher. Hundreds of buildings burned down. Moscow was covered by smog and millions of people in the Russian capital struggled to have access to fresh air. The wildfires in Russia took place a few months after a tragic earthquake in Haiti, an incident that had triggered a wave of innovation around crisis mapping and digital innovation. Some of the technologies that had been used in response to the Haiti earthquake could be also seen used in response to Russia's wildfires.

First, the Russian Internet was actively used to map disaster and collect volunteerbased geographic information (VGI) about the emergency (the notion of VGI was introduced by Goodchild (2007)). This included the active participation of GIS experts, open data activists and members of the OpenStreetMap community. Some fire-mapping activities were supported by environmental organisations such as Greenpeace and the satellite monitoring company Scanex. A map of fires was developed by Yandex (http://pozhar.yandex.ru). The "Kosmosnimki" company, which is linked to Scanex, developed the platform "Fires" (http://fires. kosmosnimki.ru which later became fires.ru) for the global mapping of wildfires. More generally, the data about fires came from various sources including usergenerated information on social media (including Facebook, Livejournal, YouTube, etc.) as well as from satellite imagery. Internet-based fire mapping sought to offer real-time information about the spread of fires in different locations in Russia.

These crisis mapping efforts were particularly important due to some Russian Internet users' mistrust of official information about the scale of the fires. While the traditional media reported that the emergency services had the wildfires under control, digitally mediated efforts to independently map the fires provided an alternative picture of the scale of the disaster. In that sense, crisis mapping went beyond the instrumental mapping of disaster, and it can be considered a source of alternative framing of the disaster (Entman, 1993), one that challenges the authorities' control over the construction of the information picture around wildfires. The role of user-generated information in the case of Russian fires, however, was not limited to creating a database of open data about disaster and crisis mapping. The role of user-driven crisis mapping was also not limited to alternative framing and exposing the real scale of the disaster. As highlighted by Morozova and Miroshnechenko (2011), the role of online networked communities went beyond information exchange and it "initiated citizen participation in real life events" (p. 148).

The information that was collected by users included the humanitarian needs of the wildfire victims as well as requests for the immediate mobilisation of volunteers to fight the fires. A particularly significant role was played by the blogging platform Livejournal. One of the first reports about the wildfires was provided by Mikhail Shlyapnikov, a blogger who lived near a village that was almost destroyed by the fire. This report was distributed promptly through social networks and it mobilised 
other bloggers to take part in the collection of various goods to help victims. A dedicated Livejournal-based community, Pozar_Ru (http://community.livejournal. com/pozar_ru/), was launched to offer a common channel of communication and a coordination of response to the wildfires. Some bloggers, including journalist Igor Chersky, went to the areas affected by the fires to gather first-hand information about real needs. The help that was provided by Internet users included not only food and clothing but also professional firefighting equipment that had been purchased by the users. Runet started to play a vital role in the mobilisation of resources that are needed to respond to a disaster and in the engagement of volunteers, as a part of the emergency response.

Russian users nevertheless faced a major challenge. A constant flow of information about fires and needs requires an efficient platform for crisis mapping, one that can aggregate information about fires, information about needs and information about available resources offered by Internet users. In addition, there is a need for an advanced mechanism to coordinate resource allocation, as well as to organise volunteering activities. One response to these challenges was provided by those who relied on the crowdsourcing platform Ushahidi, which had been used a few months earlier in response to an earthquake in Haiti. The crowdsourcing platform "Help Map" (Russian-fires.ru) offered to connect those who needed help with those who could offer assistance, relying on a permanent aggregation of data about fires, needs and resources. In addition to online platforms, "Help Map" offered an offline volunteer-based coordination centre for fire response. The platform also supported synergy between users and different NGOs including the official charity organisation of the Russian Church.

Data from the "Help Map" was also integrated within the map of fires that had been developed by Yandex, which constitutes an example of cross-platform collaboration between a major Internet company and an independent citizen-driven online initiative. The capacity of digital platforms to support alternative top-down systems of emergency response coordination relies not only on the generation of usergenerated data but also of user-generated metadata. "Help Map" and other crowdsourcing platforms, as well as Twitter, allow users to generate new categories and tags, which support the development of an alternative system of crisis classification. The development of a structure of categories that is driven by users can be addressed as the folksonomy of emergency situations (Asmolov, 2015a).

The development of "Help Map" highlighted the fact that Russian Internet users had taken a step forward, moving from a variety of initiatives and a general willingness to volunteer to a user-coordinated emergency response operation. According to Morozova and Miroshnechenko (2011), “The 'Help Map' project is an example of an 'ad hoc' electronic resource developed by a networked community in emergency situations" (p. 148). In just a few days "Help Map" was visited by more than 100,000 users and attracted the attention of the mass media. According to Meier (2015), "Help Map" was also one of the biggest Ushahidi deployments worldwide at that time. Later, it received a Runet Award, a national award sponsored by the Russian Ministry of Communication, as the best Internet project of the year in 
the "State and Society" category, and several other prizes. The project was also one of the first significant crowdsourcing initiatives in the history of Runet.

Scholars highlight that "citizen-driven ad hoc electronic resources are a type of project that emerges when the state's structures are not capable of reacting to new issues that are thrown up by emergency situations" (Morozova \& Miroshnechenko, 2011, p. 148). According to Yanitzky (2010, online), the role of social media in response to the wildfires in 2010 highlights that "the network systems not only performed faster and more flexibly in the mobilisation of resources, and in a way that is not available for mobilisation through 'vertical structures' of political and social action, but they also provided more reliable information, which also included early warnings about critical situations that were developing on the ground". Yanitzky also suggests that the way social media were used in response to wildfires bears a resemblance to Kropotkin's concept of mutual aid, which highlights that cooperation is not possible without trust.

The role of Runet in response to wildfires can be conceptualised through a number of contemporary concepts from social and political science. For instance, the role of Runet users in response to wildfires can be addressed as a manifestation of various segments of networking power (Castells, 2011), the mobilisation of the "fifth estate" (Dutton, 2009) and the emergence of networks of trust that support digitally mediated mutual aid (Benkler, 2011). The role of Runet in the facilitation of emergency response in a sociopolitical context can be also explored using the concept of limited statehood (Livingston \& Walter-Drop, 2014; Risse, 2011). The latter would suggest that the users' self-organisation that relies on digital platforms can be seen in situations where citizens believe that the state is not capable of providing an adequate emergency response:

In an environment of low trust in government and other institutions, interpersonal communication networks become tools for coping with crises when public mechanisms for effective communication fail. Ordinary Russians develop their own unique strategies of communication and pragmatic competence to survive and maintain control over their environment. (Samoilenko, 2016, p. 406).

In that light, the practices that were developed by Runet users in response to wildfires can be seen as an alternative user-driven mode of governance for an emergency situation (Asmolov, 2014).

Traditional institutions including the Ministry of Emergency Response started to develop their own online presence in January 2008, when the ministry launched an Internet portal that dealt with emergency situations (Morozova \& Miroshnechenko, 2011, p, 149). One of the major purposes of the state's online presence is to broadcast alerts about hazards and potential emergencies. That said, it seems that the state predominantly approaches Internet users as a passive audience that needs to be informed, rather than as a potential partner for collaboration. Morozova and Miroshnechenko (2011) highlight that they were not able to find any reference to the value of the resources of the networked community in any official or informal documents produced by Russian emergency response institutions. According to these writers "Ignoring the constructive potential [of networked communities] is a 
consequence of the rejection of Internet users as 'Aliens' due to their non-conformism and criticism of the authorities" (pp. 149-150).

This notion of considering Internet users as "aliens" gave rise to several different types of state-driven online policy. For instance, in the case of wildfires some pro-government youth movements allegedly used digital technologies to create a semblance of participation in the emergency response through the dissemination of staged photos showing the putting out of fires (Asmolov, 2010). Another way traditional state institutions addressed the role of digital platforms in emergency situations was by developing a tool for the management of volunteers. The website Dobrovoletz.rf (Volunteer.Rf) was developed by RosSoyuzSpas, an organisation of emergency-related volunteers that was associated with the Ministry of Emergency Situations (MCHS). Unlike "Help Map" and various pages on social media that offered a horizontal and transparent model for the coordination of emergency response by users, Dobrovoletz.rf proposed a model based on a registry of volunteers that is managed hierarchically in a non-transparent way by RosSoyuzSpas administrators.

The Dobrovoletz.rf platform highlighted the tension between the role of ICTs in the engagement of people in emergency response and controlling the resources of people in situations of crisis. The model of a platform that is driven by an intent to control the resources of Internet users, rather than to use these resources, has been conceptualised as "vertical crowdsourcing" (Asmolov, 2015b). Another major tension can be seen around the state's approach to the role of ICTs in an emergency with regard to user-generated data. Apparently, there is a conflict between seeing data as something that contributes to awareness of a situation and enables a support response and seeing data as a source of criticism which challenges the state's monopoly over the information picture of a disaster. The latter transforms the state's perspective on the role of social media from a resource that contributes to emergency response to a resource that can be considered a reputational threat and that may have a negative impact on the institutional apparatus.

Innovative forms of citizen use of digital platforms as well as tension arising between volunteers reliant on digital platforms and traditional institutional structures again emerged 2 years after the wildfires, this time in reaction to floods in the Krymsk area (2012). In 2013, in response to floods in Russia's Far East, a group of volunteers tried another model of digitally mediated response due to the remoteness of the disaster from central Russia. The ad hoc platform Amur13 was used by a small group of volunteers for crowdfunding. The financial assistance that came from a broad group of Russian Internet users allowed goods to be purchased and sent to the few volunteers active in the disaster area and distributed to support the affected local community and local responders.

The role of platforms for emergency response, however, has now gone beyond specific emergency situations. Digital platforms have contributed to the development of networks of citizen resilience that allows people to be mobilised around emergency situations on an everyday basis. For instance, "Liza Alert", a digital search and rescue online group and platform, allows the immediate mobilisation of volunteers once there is a report that someone has gone missing (Asmolov, 2011). "Liza 
Alert" volunteers, as well as members of a few additional search and rescue projects that use digital platforms for the mobilisation of volunteers and the coordination of searches (e.g. the Extremum group that is based in the Saint Petersburg area), illustrate how ICTs can help to save the lives of specific people in everyday life. One may suggest that emergency-related digital online projects also inspire digital innovation in the sphere of urban and political activism, when crowdsourcing platforms start to be used for the mapping of urban problems and to facilitate citizen activism to resolve them. For instance, according to Russian political activist Alexey Navalny, the model of "Help Map" was used for his first crowdsourcing project, which mapped potholes on roads (Navalny, 2010). This example suggests how innovation comes to be diffused, moving from crisis-related activism to other spheres of digitally mediated citizen participation.

Emergency response continues to be an area of constant digital innovation. That includes the development of algorithms and AI applications to deal with the increasing size of big data sets around emergency situations. The response to the hurricane that took place in Moscow in 2017 highlights that the development of efficient and targeted alerting systems remains a challenge. While big Russian Internet companies such as Yandex had developed new innovative forms of mapping that allowed hurricanes and rainfall to be followed in real time, the state's SMS-based alerting system was accused of being late and providing information that was neither instrumental nor helpful to people in the affected areas.

To sum up, the case of Runet demonstrates how in emergency situations digital innovation has not only contributed to people's increased situational awareness but also challenged the state-sponsored framing of the emergency. Furthermore, digital mapping has provided actionable data that supports the mobilisation of users' resources and the coordination of user-driven response. This analysis illustrates the role of Runet in increasing transparency around emergency situations, in supporting efforts to hold state institutions accountable in order to improve their emergency response and in facilitating the self-organisation of Internet users to respond to the emergency. It also highlights the tension between institutions' top-down efforts to control the information picture of a disaster and the volunteers and users' bottom-up efforts to provide an independent picture of the situation and allow the horizontal mobilisation of the resources of the users by the users around goals that are defined by the users.

\subsection{Internal and External Conflicts: Participation and Political Innovation}

The third set of crisis situations under discussion is that of conflicts. The role of Runet in conflicts provokes the asking of several questions, including how digital platforms mediate the relationship between their users and the conflicts, how relations between institutional actors and users are manifested in a conflict situation and 
what the major forms of digital innovation are that are driven by conflict situations. Conflict can be divided into two main types of situations. The first type is that of internal political conflict, which includes conflict within a state such as citizendriven protest against the authorities. The second type is that of external conflict, which includes cases of international conflict between state actors.

Numerous scholars have explored the role of Runet in empowering the Russian political opposition (Greene, 2014; Oates, 2013). On the one hand, Runet can be considered as an alternative source of information which "offer[s] alternative frames for discussing news and politics" and "constitutes an independent alternative to broadcast and print media" (Alexanyan, Barash, Etling, \& Faris, 2012). On the other hand, Runet is used a platform for the mobilisation and self-organisation of people in situations of political protest.

The protests following the parliamentary elections in winter 2011-2012 provide an illustration of the role of Runet in a context of political crisis. The protests were supported by the development of various digital projects including platforms that support new forms of data collection about electoral fraud (e.g. The Map of Electoral Violations by NGO Golos), independent tools for counting the number of participants in protests (e.g. "The White Counter" tool), tools for the simplification of symbolic production and the sharing of protest-related content, tools for the mobilisation and engagement of people for electoral monitoring and participation in demonstrations, and tools that allow new forms of decentralised connective action (Bennett \& Segerberg, 2012) as in the case of the White Circle protest. In the latter case, a dedicated platform (Feb26.ru) supported the self-organisation of people enabling them to create a live chain around the centre of Moscow.

Situations of internal crisis can be considered moments of accelerated digital political innovation, when both sides of a conflict seek to develop technological solutions to increase their capacity to collect data and mobilise people as well as to neutralise the innovations that have been introduced by the opposite side (Asmolov, 2013). From this perspective, every new political crisis presents a new cycle of digital innovation on both sides of the conflict. Digital innovation can also be viewed as something that can potentially change the balance of power between opposing sides of the conflict, though every shift of balance towards one side is answered by the other side with efforts to restore the balance. For instance, the increasing role of Vkontakte social networking groups in the facilitation of a diversity of forms of participation in protest activity was addressed by increasing pressure on the founder of the network, Pavel Durov, who in turn publicly refused to collaborate with the authorities. What started as a request from the Russian security agencies for the disclosure of data from the private communications of Vkontakte users ended with Vkontakte changing hands and Durov leaving Russia.

The other type of conflict is that which goes beyond the borders of the state. The Internet is often considered as a space for information warfare between various state actors, in which digital platforms can be used both for propaganda and for infrastructural cyberattacks against a rival state and its citizens. That said, while focusing on international conflict as an additional type of crisis in order to examine the role of Runet, it is particularly fruitful to approach this type of conflict from the point of 
view of Internet users. This approach involves exploring how digital platforms distinguish between everyday life and conflict through users' immersion in the conflict and by offering users a set of roles in relation to the conflict.

The conflict between Russia and Ukraine presents a distinctive case, since while it involves conflict between two independent sovereign states, many citizens of both countries share the same Russian-speaking Internet space and use the same digital platforms including social networking websites that were developed in Russia. The opportunity for immediate direct communication between users from both sides of the conflict potentially contributes to the scale of its psychological tension and online hostility. Social networks integrated general information about the conflict with interpersonal interaction between users, which contributed to immersion within the conflict even if the users were remote from the location of conflict. The latter can potentially lead to the destruction of existent social ties, e.g. large-scale "unfriending" practices when people decide to cut their ties on social networking platforms due to the political positions of their friends (Asmolov, 2018). The destruction of social ties supported by the proliferation of trolling practices as well as a flow of disinformation contributes to the scale of online aggression. That type of communication not only follows the conflict but also constitutes the conflict by changing the social structure of the societies that have been involved in that conflict.

As with situations of internal crisis, international conflicts give rise to various conflict mapping tools and platforms that provide information about the conflict from both sides. Moreover, dedicated platforms and crowdsourcing practices are used to verify information and challenge the credibility of the sources that are linked to the rival side in the conflict. The collection of data relies not only on crowdsourcing but also on the analysis of satellite imagery, as in the case of the reports that are developed by the Conflict Intelligence Team, a Russian online group of conflict investigators. The latter can be considered as practices of Open Source Intelligence analysis that have been adopted by various actors to investigate conflicts. Data collection, together with its proliferation and verification, can be considered as a form of user engagement in conflict-related activities.

As well as in cases of natural disaster and internal political crisis situations, international crisis situations are also followed by digital innovation that enable various forms of user participation in the conflict, which can be conceptualised as "participatory warfare". This includes participation in information warfare when users from both sides are permitted to create content and disseminate content that represents the position of one of the sides. Some hacktivist projects allow the simplification of participation in hacking activities for common users, when, for instance, users are able to contribute their computer resources to a botnet. Conflict mapping projects allow their users to collect and share intelligence from the conflict zone as well as take part in data verification and data analysis that is also related to the conflict. Crowdfunding initiatives allow their users to sponsor military activities, including taking part in purchasing military equipment. Finally, some platforms are used for recruiting volunteers for offline participation in the conflict.

To sum up, digital innovation simplifies users' participation in conflict through offering a range of possible forms of activity in relation to warfare. As well as 
immersive practices, the participatory practices can also be considered as something that constitutes the conflict through increasing the scope of social participation in the conflict and making this conflict part of everyday reality even in areas that are remote from the conflict. From this perspective, Runet has contributed to the socialisation of conflict (Schattschneider, 1975), which has increased the scope for participation in conflict on both sides. In the case of both internal and international conflicts we can see that Runet has played a role not only in the construction of different images of a given crisis but also in the mobilisation of users' resources in relation to such crises.

\section{Conclusion}

This chapter proposes that the Russian Internet has two different, though interrelated, faces. The first face is that of Runet in everyday life. The second face is Runet in situations of crisis. To explore the "crisis side" of Runet, this chapter has addressed a variety of crisis situations including terror attacks, natural disasters, political protests and international conflicts. Despite the diversity of these situations, examination of the role of Runet in crisis situations allows us to identify a number of common features of the Russian Internet space and the crisis-related practices of Russian Internet users. Runet's users generate crisis-related data that contributes to shaping a general picture of crisis and situational awareness. That data increases the transparency around crisis situations in cases when the state's control over information flow seeks to diminish the scale of the emergency. The role of Runet in increasing transparency around a crisis also contributes to citizens' capacity to hold the authorities accountable regarding their management of the emergency response.

In crisis situations Runet reveals new faces in the digital crowd and new functions of digital sourcing. The role of user-generated data in exposing the scale of a crisis and in providing information about specific needs allows users to go beyond passive spectatorship. The examination of natural disasters highlights that user-generated data can be considered as actionable data that support actions by individual users as well as by NGOs. Runet offers a range of participatory tools that mediate action and facilitate the self-organisation of individual users in a crisis situation. From that perspective, one can argue that Runet appears to play an important role in shaping the relations between users and crisis situations while offering diverse forms of potential action in relation to a given crisis. In that sense, the role of Runet in constructing the picture of a crisis and the mobilisation of users' resources to address that crisis are interrelated. That is consistent with that double role of technological mediation as a mediation of meanings (Silverstone, 2002) around specific situations and a mediation of activities (Kaptelinin, 2014) in regard to the constructed situation.

The case of Runet also illustrates how different types of crisis situation serve as moments for innovation (Sellnow \& Seeger, 2013). This includes not only technological but also socialpolitical innovation that, as suggested by Solnit (2010), offers a window of opportunity towards a new type of society. At the same time, while many 
features concerning the role of digital technology in the crisis situations discussed here can be found in other countries, a number of aspects can be considered distinctive of Runet. A central aspect is related to the structure of power relations between state and citizens and the specific role of crisis situations in Russian history and Russian political culture over the last few hundred years.

This chapter illustrates that the role of Runet in crisis situations is on the one hand a display of citizens' mistrust towards authorities and citizens' interest in developing an independent capacity to address crises. On the other hand, exploring the role of Runet in crisis situations illustrates the state's interest in controlling the digital crowd, specifically the generation of content which threatens state control over the representation of a crisis, as well as the state's concern with the digitally mediated independent self-organisation of Internet users. From this perspective, Runet demonstrates that every type of crisis, including natural disasters, political protest and international conflict, can be seen to generate tension between user-driven horizontal mobilisation (e.g. the case of the "White Circle" platform and the "Help Map") and state-driven vertical mobilisation (e.g. the case of Dobrovoletz.rf and initiatives for user engagement in information warfare) around the crisis. The core of this tension is control over how the resources of the digital crowd are used in a crisis situation, which includes symbolic resources for the construction of crisis and a diversity of other resources that can be applied as part of users' engagement around a crisis. In that context, the chapter demonstrates the vital role of Runet in both framing the crisis and shaping the structure of the participation of users in crisis situations.

The exploration of power relations cannot be separated, however, from the sociocultural context which focus on the examination of Runet's role for normative and social transformation. This chapter proposes that in the case of crisis situations, Runet can be associated with the emergence of a crisis-related social system, which relies on a different type of normative structure and offers new types of roles to Internet users. This includes the continuous efforts of its users to collect actionable information about the real scale of the crisis and the horizontal coordination of mutual aid which relies on the mobilisation of the resources of the digital crowd. Runet plays a vital role in mediating the transition from everyday life to crisis, which is followed by change in the structure of social systems and the role of users. At the same time, projects like "Liza Alert" use digital platforms in order to continuously support the construction of crisis awareness as a part of everyday life and sustain crisis-related normative modes of behaviour beyond large-scale crisis situations.

Finally, it may be argued that various types of emergencies seem to be a central driver in the development of Runet. This chapter has demonstrated how crisis situations can be considered as moments of accelerated innovation, when users develop new digital platforms and new digital practices including platforms for crisis mapping and tools for the facilitation of collective action. For instance, crowdsourcing practices that were introduced during the response to wildfires in 2010 were actively adapted later in various fields including the struggle against corruption and urban activism. At the same time, situations of crisis, including political protest, international conflict and natural disaster, can also be considered to be moments for the accelerated development of new forms of control. Therefore, 
such tendencies as the sovereignisation and securitisation of Runet may also have their roots in specific crisis situations that force institutional structures to address new political challenges.

To conclude, this chapter has shown that Runet indeed follows the vision of the "mobilising wheel" that was put forward by Arkady Gaidar. It takes part in defining a given crisis and supporting the mobilisation of people around that crisis, while the act of mobilisation actually defines the situation as a crisis. It also constitutes the nature of the organisation of people around crisis situations. At the same time, the questions that were focal in Gaidar's "wheel" remain so for Runet as well: What are the rules that regulate how the "wheel" can be used, who is connected to the "wheel", who has the right to turn the wheel so as to mobilise the network and, finally, is just any user able to create and use his or her own "digital wheel"?

\section{References}

Alexanyan, K., Barash, V., Etling, B., \& Faris, R. (2012). Exploring Russian cyberspace: Digitallymediated collective action and the networked public sphere. Berkman Center Research Publication, no 2012-2.

Asmolov, G. (2009a, October 29). Russia: How passengers of "Nevsky Express" tell their stories through social media. Global Voices Online. Retrieved June 14, 2018, from https://globalvoices. org/2009/11/29/russia-how-passengers-of-nevsky-express-tell-their-stories-through-socialmedia/

Asmolov, G. (2009b, December 12). Russia: Online forum beats media in covering night club fire. Global Voices Online. Retrieved June 15, 2018, from https://globalvoices.org/2009/12/05/ russia-online-forum-beats-media-in-covering-night-club-fire/

Asmolov, G. (2010, September 8). Russia: Bloggers clash with the ruling party. Retrieved June 12, 2018, from https://globalvoices.org/2010/09/08/russia-bloggers-clash-with-the-ruling-party/

Asmolov, G. (2011, October 17). Russia: Networked volunteers save lives of missing children. Global Voices Online. Retrieved July 16, 2018, from http://globalvoicesonline.org/2011/10/17/ russia-networked-volunteers-save-lives-of-missing-children/

Asmolov, G. (2013). Dynamics of innovation and the balance of power in Russia. In M. M. Hussain \& P. N. Howard (Eds.), State. Power 2.0 authoritarian entrenchment and political engagement worldwide (pp. 139-152). Farnham: Ashgate.

Asmolov, G. (2014). Natural disasters and alternative modes of governance: The role of social networks and crowdsourcing platforms in Russia. In S. Livingstone \& G. Walter-Drop (Eds.), Bits and atoms. Information and communication technology in areas of limited statehood. Oxford: Oxford University Press.

Asmolov, G. (2015a). Crowdsourcing and the folksonomy of emergency response: The construction of a mediated subject. Interactions: Studies in Communication \& Culture, 6(2), 155-178.

Asmolov, G. (2015b). Vertical crowdsourcing in Russia: Balancing governance of crowds and state-citizen partnership in emergency situations. Policy \& Internet, 7(3), 292-318.

Asmolov, G. (2018). The disconnective power of disinformation campaigns. Journal of International Affairs, 71(1.5), 69-76.

Asmolov, G., \& Kolozaridi, P. (2017). The imaginaries of RuNet: The change of the elites and the construction of online space. Russian Politics, 2, 54-79.

Barton, A. H. (1969). Communities in disasters: A sociological analysis of collective stress situations. Garden City, NY: Doubleday, Anchor Books. 
Benkler, Y. (2011). The penguin and the leviathan: How cooperation triumphs over self-interest. New York: Crown Business.

Bennett, W. L., \& Segerberg, A. (2012). The logic of connective action. Information, Communication \& Society, 15(5), 739-768.

Bertrand, E. (2012). Constructing Russian power by communicating during disasters: The forest fires of 2010. Problems of Post-Communism, 59(3), 31-40.

Castells, M. (2011). A network theory of power. International Journal of Communication, 5, $773-787$.

Castillo, C. (2016). Big crisis data: Social media in disasters and time-critical situations. Cambridge: Cambridge University Press.

Coombs, W. T. (2010). Parameters for crisis communication. In W. T. Coombs \& S. J. Holladay (Eds.), The handbook of crisis communication (pp. 17-53). Malden: Blackwell.

Coombs, W. T., \& Holladay, S. J. (2004). Reasoned action in crisis communication: An attribution theory-based approach to crisis management. In D. P. Millar \& R. Heath (Eds.), Responding to crisis. A rhetorical approach to crisis communication (pp. 95-115). Mahwah, NJ: Lawrence Erlbaum.

Cuny, F. (1983). Disasters and development. Oxford, UK: Oxford University Press.

Dutton, W. (2009). The fifth estate emerging through the network of networks. Prometheus, 27(1), $1-15$.

Engeström, Y. (1987). Learning by expanding: An activity-theoretical approach to developmental research. Orienta-Konsultit Oy: Helsinki.

Entman, R. (1993). Framing: Toward clarification of a fractured paradigm. Journal of Communication, 43(4), 51-58.

Gaidar, A. (1940/1973). Timur and his squad. Moscow: Progress Publishers.

Goodchild, M. (2007). Citizens as sensors: The world of volunteered geography. GeoJournal, 69 (4), 211-221.

Greene, S. (2014). Moscow in movement: Power and opposition in Putin's Russia. Palo Alto, CA: Stanford University Press.

Hewitt, K. (1998). Excluded perspectives in the social construction of disaster. In E. L. Quarantelli (Ed.), What is a disaster? Perspectives on the question (pp. 75-92). New York: Routledge.

Hutchby, I. (2001). Technology, texts, and affordances. Sociology, 35(2), 441-456.

James, E. H., \& Wooten, L. P. (2005). Leadership as (un)usual: How to display competence in times of crisis. Organizational Dynamics, 34(2), 141-152.

Kaptelinin, V. (2014). The mediational perspective on digital technology: Understanding the interplay between technology, mind and action. In S. Price, C. Jewitt, \& B. Brown (Eds.), The Sage handbook of digital technology research (pp. 203-217). London: Sage.

Kuchinskaya, O. (2014). The politics of invisibility. Public knowledge about radiation health effects after Chernobyl. Boston, MA: MIT.

Leontiev, A. N. (1978). Activity, consciousness, and personality. Englewood Cliffs, NJ: Prentice Hall.

Lerbinger, O. (1997). The crisis manager: Facing risk and responsibility. Mahwah, NJ: Lawrence Erlbaum.

Lipman, M. (2006, September 4). After Beslan, the media in shackles. Washington Post. Retrieved April 14, 2018, from http://www.washingtonpost.com/wp-dyn/content/article/2006/09/03/ AR2006090300743.html

Livingston, S., \& Walter-Drop, G. (2014). Introduction. In S. Livingston \& G. Walter-Drop (Eds.), Bits and atoms information and communication technology in areas of limited statehood (pp. 1-14). New York: Oxford University Press.

Machleder, J., \& Asmolov, G. (2011). Social change and the Russian network society, redefining development priorities in new information environments. Internews Network [online, August 2011, last modified May 23, 2012]. Retrieved May 27, 2018, from http://www.internews.org/ research-publications/social-change-and-russian-network-society 
Meier, P. (2011). New information technologies and their impact on the humanitarian sector. International Review of the Red Cross, 93(884), 1239-1263.

Meier, P. (2015). Digital humanitarians: How big data is changing the face of humanitarian response. Boca Raton, FL: CRC.

Morozova, E. V., \& Miroshnechenko, I. V. (2011). Networked communities in emergency situations: New opportunities for citizens and for government [Setevieye soobshestva $\mathrm{v}$ usloviyah chrezvichaynyh situatziy: noviye vozmozhnosti dlya grazhdan i dlya vlasti]. Polis. Political Studies, 1, 140-152.

Navalny, A. (2010, September 7). Ushahidi for pot-holes [Ushahidi po Uhabam]. Retrieved June 12, 2018, from http://navalny.livejournal.com/500765.html

Oates, S. (2013). Revolution stalled: The political limits of the internet in the post-soviet sphere. Oxford: Oxford University Press.

Pelling, M. \& Dill, K. (2006). “Natural disasters” as catalysts of political action (pp. 4-6). ISP/NSC Briefing Paper 06/01. London: Chatham House.

Peterson, D. J. (2005). Russia and the information revolution. Santa Monica, CA: Rand Corporation.

Raab, N. (2011). Democracy burning? Urban fire departments and the limits of civil society in late Imperial Russia, 1850-1914. Montreal and Kingston: McGill-Queen's University Press.

Risse, T. (2011). Governance in areas of limited statehood: Introduction and overview. In T. Risse (Ed.), Governance without a state? Policies and politics in areas of limited statehood. New York: Columbia University Press.

Roffey, R. (2014). Climate change and natural disasters: A challenge for Russian policymakers. Stockholm: Försvarsdepartementet/Ministry of Defence. Retrieved May 28, 2016, from http:// www.foi.se/report?rNo=FOI-R\%2D\%2D3874\%2D\%2DSE

Rosenthal, U., \& Kouzmin, A. (1993). Globalizing an agenda for contingencies and crisis management. Journal of Contingencies and Crisis Management, 1(1), 1-12.

Samoilenko, S. (2016). Crisis management and communication research in Russia. In A. Schwarz, M. W. Seeger, \& C. Auer (Eds.), The handbook of international crisis communication research (pp. 397-410). Malden: Wiley.

Schattschneider, E. E. (1975). The semisovereign people: A realist's view of democracy in America. Harcourt Brace College Publishers.

Schmidt, H., \& Teubener, K. (2006). "Our runet" ? Cultural identity and media usage. In H. Schmidt, K. Teubener \& N. Konradova (Eds.), Control + shift. Public and private usages of the Russian Internet (pp. 14-20).

Schwarz, A., Seeger, M. W., \& Auer, C. (2016). Significance and structure of international risk and crisis communication research. Toward an integrative approach. In A. Schwarz, M. W. Seeger, \& C. Auer (Eds.), The handbook of international crisis communication research (pp. 1-10). Malden: Wiley.

Sellnow, T. L., \& Seeger, M. W. (2013). Theorizing crisis communication. Malden: WileyBlackwell.

Silverstone, R. (2002). Complicity and collusion in the mediation of everyday life. New Literary History, 33, 745-764.

Soldatov, A., \& Borogan, I. (2015). The Red Web. The struggle between Russia's digital dictators and the new online revolutionaries. New York: Public Affairs.

Solnit, R. A. (2010). Paradise built in hell: The extraordinary communities that arise in disaster. New York: Penguin.

Sorokin, P. A. (1942). Man and society in calamity: The effects of war, revolution, famine, pestilence upon human mind, behavior, social organisation and cultural life. New York: Dutton.

Vygotsky, L. S. (1978). Mind in society: The development of higher psychological processes. Cambridge, MA: Harvard University Press.

Weick K. E. (1993). The collapse of sensemaking in organizations: The Mann Gulch disaster. Administrative Science Quarterly, 38(4), 628-652. 
Yanitzky, O. N. (2010, September 7). Fires, people, networks [Pozhary, seti, lyudi]. Retrieved June 28, 2018, from http://www.isras.ru/blog_yan_12.html

Ziemke, J. (2012). Crisis mapping: The construction of a new interdisciplinary field? Journal of Map \& Geography Libraries: Advances in Geospatial Information, Collections \& Archives, 8 (2), 101-117.

Open Access This chapter is licensed under the terms of the Creative Commons Attribution 4.0 International License (http://creativecommons.org/licenses/by/4.0/), which permits use, sharing, adaptation, distribution and reproduction in any medium or format, as long as you give appropriate credit to the original author(s) and the source, provide a link to the Creative Commons licence and indicate if changes were made.

The images or other third party material in this chapter are included in the chapter's Creative Commons licence, unless indicated otherwise in a credit line to the material. If material is not included in the chapter's Creative Commons licence and your intended use is not permitted by statutory regulation or exceeds the permitted use, you will need to obtain permission directly from the copyright holder. 